\title{
The curiously long absence of cooking in evolutionary thought
}

\author{
R. Wrangham ${ }^{1}$
}

Published online: 8 April 2016

(C) Psychonomic Society, Inc. 2016

\begin{abstract}
Beran et al. (2015, p. 1) characterized the idea that "cooked food was integral in human evolution" as a "longheld hypothesis" favored by Darwin and Engels. In fact, however, although Darwin and Engels considered the use of cooked food to be an important influence on behavior and society, neither of them suggested that its effects were evolutionary in the sense of affecting biology. Explicit discussion of the possible evolutionary impacts of cooking did not begin until the twentieth century.
\end{abstract}

Keywords Evolutionary thought $\cdot$ Human adaptation

In a recent critique of Warneken and Rosati (2015), Beran et al. (2015, p. 1) referred to "the long-held hypothesis that cooked food was integral in human evolution (Darwin, 1874/ 1998; Engels, 1876/1953; Wrangham, 2009)." Certainly Darwin and Engels treated cooking as a significant human achievement with important consequences for cultural adaptation. Darwin (2006 [1871], p. 855) noted that cooking enabled a wider breadth of diet: "Man ... has discovered the art of making fire, by which hard and stringy roots can be rendered digestible, and poisonous roots or herbs innocuous." Engels (1975 [1876], p. 9) referred to the control of fire as an advance "of decisive importance" because it "shortened the digestive process, as it provided the mouth with semidigested food, as it were." Surprisingly, however, neither of them proposed that it had any effects on evolutionary biology. This raises an interesting question. Cooked food is a universal

\section{R. Wrangham}

wrangham@fas.harvard.edu

1 Department of Human Evolutionary Biology, Harvard University, 11 Divinity Avenue, Cambridge, MA 02138, USA feature of human societies that has enormous biological consequences and is not found in other organisms. So why did those eminent Victorians, like most evolutionists, not discuss the possibility that the adoption of cooking could have influenced biological evolution?

I suggest that both men were inhibited from doing so by their assuming that the species that first controlled fire was Homo sapiens ("man"). Their statements on this point were clear. Darwin referred to "This discovery of fire, probably the greatest ever made by man . ..” Engels (1975 [1876], p. 9) opined that cooking and the domestication of animals, "directly became new means of emancipation for man." In ascribing the discovery of cooking to humans, these writers were following a long tradition. Hippocrates, writing around the $4^{\text {th- }} 5^{\text {th }}$ century BCE, likewise considered that humans were the inventors of cooking. He conjectured that humans would have suffered seriously from stomach pains until they learned to eat cooked food (Schiefsky, 2005). If the species that discovered cooking was indeed Homo sapiens, it is understandable that Darwin, Engels and Hippocrates presented cooking as a purely cultural achievement.

It would take decades after Darwin, and emerging evidence about the time-scale and stages of human evolution, for different approaches to be taken. Pre-human apes were first recognized in 1924 with the discovery of Australopithecus africanus (Dart, 1925). By the mid-1930s pre-sapiens forms of human were known from Europe, the Middle East and Indonesia (Tattersall, 2012). Evolutionary ideas about cooking were then proposed for the first time. Boas (1938) imagined that cooking might have helped advance what he called the domestication of humans, including gracilization of parts of the skeleton. Later Coon (1954) suggested vaguely that cooking was "the decisive factor in leading man from a primarily animal existence into one that was more fully human." Brace et al. (1987) proposed that tooth size had declined in 
proportion to the amount of time that populations had been cooking. Aiello and Wheeler (1995) argued that cooked food could have allowed mid-Pleistocene brain expansion. Wrangham et al. (1999) proposed that cooking influenced human skeletal anatomy, while Wrangham and ConklinBrittain (2003) claimed that pre-agricultural humans were obligate consumers of cooked food.

The idea that cooking shaped human evolution is now widely accepted, but the question of when it had its major effects is a matter of debate. There are two main proposals.

The "late" scenario suggests that the first control of fire came between 500,000 and 250,000 years ago (Zink and Lieberman, 2016). The merit of this idea is that there is more direct archaeological evidence of fire in those later times than earlier.

The principal alternative is that already by ca. 1.8 million years ago, Homo erectus controlled fire and ate cooked food. The evidence is that compared to earlier forms H. erectus had a small mouth and small blunt molars, and has been reconstructed as having a smaller gut. These features are difficult to explain unless $H$. erectus had year-long access to the soft, easily digested food that cooking provides. A supporting argument comes from considering how $H$. erectus faced the threat of nocturnal predators. $H$. erectus was so poorly adapted to climbing that unlike its tree-climbing ancestors, it must have slept on the ground and needed fire to protect against predators. Direct records of fire control are elusive in the distant past but there is strong evidence for $H$. erectus using fire at 1 million years ago (Berna et al., 2012). These points imply that fire and cooking were first used by a pre-human species which then became H. erectus (Gowlett \& Wrangham, 2013).

The early hypothesis is relevant to Beran et al.'s (2015) critique of Warneken \& Rosati (2015). Beran et al. (2015) argued that "when gauging the advent of uniquely human traits" only species from Homo erectus onwards should be studied. But the proposal that Warneken \& Rosati addressed with their experiments was that the emergence of Homo erectus depended on a late australopithecine discovering the advantages of the control of fire. Clearly, therefore, living great apes were an appropriate model. Given their slightly smaller brains and presumably reduced cognitive capacities compared to those of australopithecines, great apes offer conservative insights into what australopithecines were likely capable of (Warneken \& Rosati, 2015). They are therefore invaluable subjects for understanding constraints on the transition from pre-human to human.

\section{References}

Aiello, L., \& Wheeler, P. (1995). The expensive-tissue hypothesis: the brain and the digestive system in human and primate evolution. Current Anthropology, 36, 199-221.

Beran, M. J., Hopper, L. M., de Waal, F. B. M., Sayers, K., \& Brosnan, S. F. (2015). Chimpanzee food preferences, associative learning, and the origins of cooking. Learning \& Behavior. Advance online publication.. doi:10.3758/s13420-015-0206-X

Berna, F., Goldberg, P., Horwitz, L. K., Brink, J., Holt, S., Bamford, M., \& Chazan, M. (2012). Microstratigraphic evidence of in situ fire in the Acheulean strata of Wonderwerk Cave, Northern Cape province, South Africa. Proceedings of the National Academy of Sciences of the United States of America, 109, E1215-E1220.

Boas, F. (1938). The mind of primitive man. New York, NY: Macmillan.

Brace, C. L., Rosenberg, K., \& Hunt, K. D. (1987). Gradual change in human tooth size in the late Pleistocene and post-Pleistocene. Evolution, 41, 705-720.

Coon, C. S. (1954). The story of man: From the first human to primitive culture and beyond. New York: Knopf.

Dart, R. A. (1925). Australopithecus africanus: The man-ape of South Africa. Nature, 115, 195-199.

Darwin, C. (2006). The descent of man, and selection in relation to sex (2nd ed.). Amherst, MA: Prometheus (Original work published 1871).

Engels, F. (1975). The part played by labour in the transition from ape to man. Peking, China: Foreign Languages Press (Original work published 1876).

Gowlett, J. A. J., \& Wrangham, R. W. (2013). Earliest fire in Africa: Towards the convergence of archaeological evidence and the cooking hypothesis. Azania: Archaeological Research in Africa, 48, 5-30.

Schiefsky, M. J. (2005). Hippocrates: On ancient medicine. Boston, MA: Brill.

Tattersall, I. (2012). Masters of the planet: The search for our human origins. New York, NY: Palgrave Macmillan.

Warneken, F., \& Rosati, A. G. (2015). Cognitive capacities for cooking in chimpanzees. Proceedings of the Royal Society B, 282, 20150229. doi:10.1098/rspb.2015.0229

Wrangham, R. W. (2009). Catching fire: How cooking made us human. New York, NY: Basic Books.

Wrangham, R. W., Jones, J. H., Laden, G., Pilbeam, D., \& ConklinBrittain, N. L. (1999). The raw and the stolen: cooking and the ecology of human origins. Current Anthropology, 40, 567-594.

Wrangham, R. W., \& Conklin-Brittain, N. L. (2003). The biological significance of cooking in human evolution. Comparative Biochemistry and Physiology, Part A, 136, 35-46.

Zink, K., \& Lieberman, D. E. (2016). Impact of meat and Lower Palaeolithic food processing techniques on chewing in humans. Nature. Advance online publication.. doi:10.1038/nature16990 